\title{
Influence of urbanisation and plants on the diversity and abundance of aphids and their ladybird and hoverfly predators in domestic gardens
}

\author{
Elise A. ROChA, Estevão N.F. SOUZA, Lewis A.D. BleAKLEY, Christopher BURLeY, Jade L. MOTT, \\ GLoRIA RUE-GLUTTING and MARK D.E. FELLOWES*
}

People and Wildlife Research Group, School of Biological Sciences, University of Reading, Whiteknights, Reading, Berkshire, RG6 6AS, UK; e-mails: m.fellowes@reading.ac.uk, eliserocha1@gmail.com, estevaonfsouza@gmail.com, I.bleakley@student.reading.ac.uk, c.burley@student.reading.ac.uk, g.rueglutting@student.reading.ac.uk, j.mott@student.reading.ac.uk

Key words. Hemiptera, Aphididae, Coleoptera, Coccinellidae, Diptera, Syrphidae, species interactions, diversity, abundance, urban ecology

\begin{abstract}
Urban gardens can harbour a high diversity of insects, which are critically important components of urban ecosystems. In this work, we investigate the richness and diversity of a major taxon of economic and ecological importance, the aphids (Hemiptera: Aphididae), and their main insect predators, the hoverflies (Diptera: Syrphidae) and ladybirds (Coleoptera: Coccinellidae), in urban gardens. We examined how variation in environmental factors associated with urbanisation (garden host plant abundance, garden plant richness, garden size, proportion of impervious surfaces in the surrounding area) directly and indirectly (via prey and predator abundance) influence the local diversity and abundance of aphids, ladybirds, and hoverflies. Sixty-seven domestic gardens located in southern England were surveyed during the peak period of aphid abundance, and the numbers and identity of aphids and their predators were recorded. We observed 45 aphid species (179917 individuals in total), 15 hoverfly species (494 individuals) and 8 ladybird species (173 individuals). We found that aphid species richness and abundance were positively associated with utilised host plant abundance and garden plant species richness. Hoverfly abundance was positively correlated with garden plant richness. The abundance of ladybirds was positively correlated with aphid abundance and garden plant species richness, and negatively associated to the proportion of impervious surfaces in the surrounding environment. The difference in responses between the two major taxa of aphid predators may reflect differences in their behaviour and natural history. Our results indicate that overall increases in urban land cover are not favourable for ladybirds as a group, and that fine scale habitat variables that are determined by garden owners have the potential to greatly affect the diversity of aphids and their primary predators.
\end{abstract}

\section{INTRODUCTION}

Urbanisation is perhaps the most extreme form of widespread anthropogenic habitat modification. Following urbanisation, most environmental variables (e.g., climate, water flow, biological diversity) are greatly altered from what previously existed (Smith et al., 2006). As a result, urbanisation can rapidly transform fundamental ecological processes (Goddard et al., 2010), which in turn can alter ecological interactions at multiple trophic levels (Kaye et al., 2006; Shochat et al., 2006). Unsurprisingly, urbanisation is considered a significant driver of species extinctions (McDonald et al., 2008; Goddard et al., 2010) and represents a major proposed cause of insect decline (McKinney, 2008; Fattorini, 2011; Jones \& Leather, 2012).

The magnitude of the effects of urbanisation depends to a marked degree on the composition, amount, and management of green spaces in cities (Marzluff \& Ewing, 2001;
Loram et al., 2007). This is because urban green spaces can mitigate the detrimental impacts of urbanisation by providing ecosystem services (e.g. nutrient cycling, rainwater drainage) and serving as refuges for plant and animal species (Goddard et al., 2010; Hennig \& Ghazoul, 2012). Domestic gardens are a major and important component of green spaces in urbanised areas (Smith et al., 2006). In the UK, the proportion of gardens in cities ranges from $35 \%$ in Edinburgh to $47 \%$ in Leicester (Loram et al., 2007). As habitats, gardens are maintained in a state of permanent succession, by the casual introduction of native (e.g. weeds and herbs) and exotic plant species (mostly ornamental), together with seasonal planned planting with frequent addition of new plants, coupled with other management decisions such as weeding, pesticide use, and mowing (e.g. Smith \& Fellowes, 2014; Smith et al., 2015). Overall, the composition of the garden flora tends to change over time,

\footnotetext{
* Corresponding author; e-mail:m.fellowes@reading.ac.uk
} 
and as a result plant diversity is high (Owen, 1981). Gardens are therefore thought to be vital for the sustenance of biodiversity in cities, although the diversity patterns of many organisms that inhabit gardens remains little explored (Goddard et al., 2010). However, ecosystem functioning and ecosystem resilience depends not only on rich communities, but also fully functioning ecological processes (Hennig \& Ghazoul, 2012).

One process of great importance is top-down control with the regulation of herbivore pest population through forces like predation and parasitism, which is essential for food web stability (Faeth et al., 2005; Hironaka \& Koike, 2013; Dale \& Frank, 2014). Urban environments often harbour large populations of herbivores that are considered pests, and their success might be a consequence of many factors such as low natural enemy numbers, reduced vegetation complexity, phenological shifts, presence of exotic host plants and urban warming (Kim, 1992; Shrewsbury \& Raupp, 2006; Raupp et al., 2010; Burkman \& Gardiner 2014). Also, management practices might benefit particular species of herbivores (Frankie \& Ehler, 1978; Meineke et al., 2014; Barratt et al., 2015). Consequently, investigating herbivores and their natural enemies might help us to understand how variance in environmental factors affects trophic dynamics and consequently the function of urban ecosystems (Burkman \& Gardiner, 2014). Local and fine scale environmental factors are one of the most important determinants of species interactions (Aronson et al., 2016); understanding those factors may provide us with insights that may help to develop strategies that promote arthropod conservation and support the provision of ecosystem services (Philpott et al., 2014).

Aphids are one of the few groups of insects that are more abundant in temperate regions than in the tropics (Brisson $\&$ Stern, 2006). About 250 species feed and reach high population numbers on agricultural crops and cause hundreds of millions of dollars in lost production each year (Oerke et al., 2012). Among these species, residential gardeners frequently encounter the green rose aphid (Macrosiphum rosae L.) or the black bean aphid (Aphis fabae Scopoli) on common urban garden plants (Brisson \& Stern, 2006). We have almost no information on how aphids respond to characteristics of urbanisation, with regards to species composition, abundance, and natural enemies. Hoverfly larvae and ladybirds are the most important predators of this group (Rotheray, 1989; Ball et al., 2013). Given their diversity and ubiquity, together with their range of relationships with host plants and insect predators, aphids and their enemies provide an excellent model system for examining how urbanisation affects insect abundance and diversity (Rocha \& Fellowes, 2018).

Hoverflies (Diptera: Syrphidae) provide varied ecosystem services: larvae contribute to pest control feeding on aphids and other insects (insectivore species) and waste decomposition (saprophagous species, eating decaying plant and animal matter), and adults are valuable pollinators (Jauker et al., 2012; Moquet et al., 2018). Hoverflies have previously been shown to be negatively associated with higher levels of urbanisation (Bates et al., 2011; Baldock et al., 2015), but how this is affected by resource availability in urban habitats is not known. Many ladybird species (Coleoptera: Coccinellidae) are important predators of aphids, coccids, mites and a variety of other arthropods, and they are of high interest because of their value as biological control agents (Giorgi et al., 2009; Obrycki et al., 2009; Weber \& Lundgren, 2009; Honek et al., 2017). Studies evaluating the vulnerability of ladybird communities to urbanisation are few. Therefore, investigating ladybird numbers coupled with changes in prey in urban environments is of great importance, since it has been hypothesized that recent decline in coccinelid numbers may be due to phenological mismatches between host plants, insect herbivores and their coccinellid predators (Honek et al., 2017).

In this work, we ask how local and fine-scale environmental factors affect the diversity of aphids and their primary predators in urban gardens. Investigating both trophic groups at the same time (herbivores and their main predators) may provide insights into which group may be more sensitive to urbanisation and its consequences. To address this knowledge gap, we investigate how variation in environmental factors (host plant abundance, garden plant richness, garden size, proportion of impervious surfaces in the surrounding area) are directly and indirectly (prey and predator abundance) associated with the local diversity and abundance of aphids, ladybirds, and hoverflies.

\section{MATERIAL AND METHODS}

\section{Study sites and sampling}

Sixty-seven domestic gardens located in Greater Reading, Berkshire, England $\left(51^{\circ} 27^{\prime} \mathrm{N}, 0^{\circ} 58^{\prime} \mathrm{W}\right)$ were selected for this study. Greater Reading is an urban area with a population of 290 000 , which covers an area of ca. $72 \mathrm{~km}^{2}$ (Office for National Statistics, 2013). These gardens were chosen from previously designated areas, which were selected by their relative position and overall representation on an urbanisation gradient that covers highly urbanised areas in the town centre, to suburban and periurban housing areas until reaching areas where the town borders on agricultural areas in the south (Fig. 1). Each target area was composed of 5-10 houses, and from each area a study garden was obtained either by the distribution of leaflets or by randomly asking "door-to-door" for volunteers willing to participate in the study. While this process was not entirely random, it was considered effective in capturing local variation in garden structure as the need of gardens of all shapes, sizes and frequency of management/gardening was emphasised in order to avoid a bias towards gardening enthusiasts (Barratt et al., 2015). Only residential gardens were selected, and their general composition and vegetation structure varied from very low management with presence of many native plants like wild flowers and herbs, and gardens with high intervention and planting management (performed by the household or professionally by third parties) with the presence of many exotic ornamental plants which tend to change frequently year to year. Each garden was located at least $240 \mathrm{~m}$ from the nearest neighbouring study garden.

Sampling occurred from mid-June 2017 until the beginning of August 2017. In each study site, every plant within reach when standing on ground was fully searched for aphids, ladybirds and hoverfly larvae. These plants comprised mainly ornamental plants, wild plants, potted plants, bushes, shrubs, herbs, aromatic 


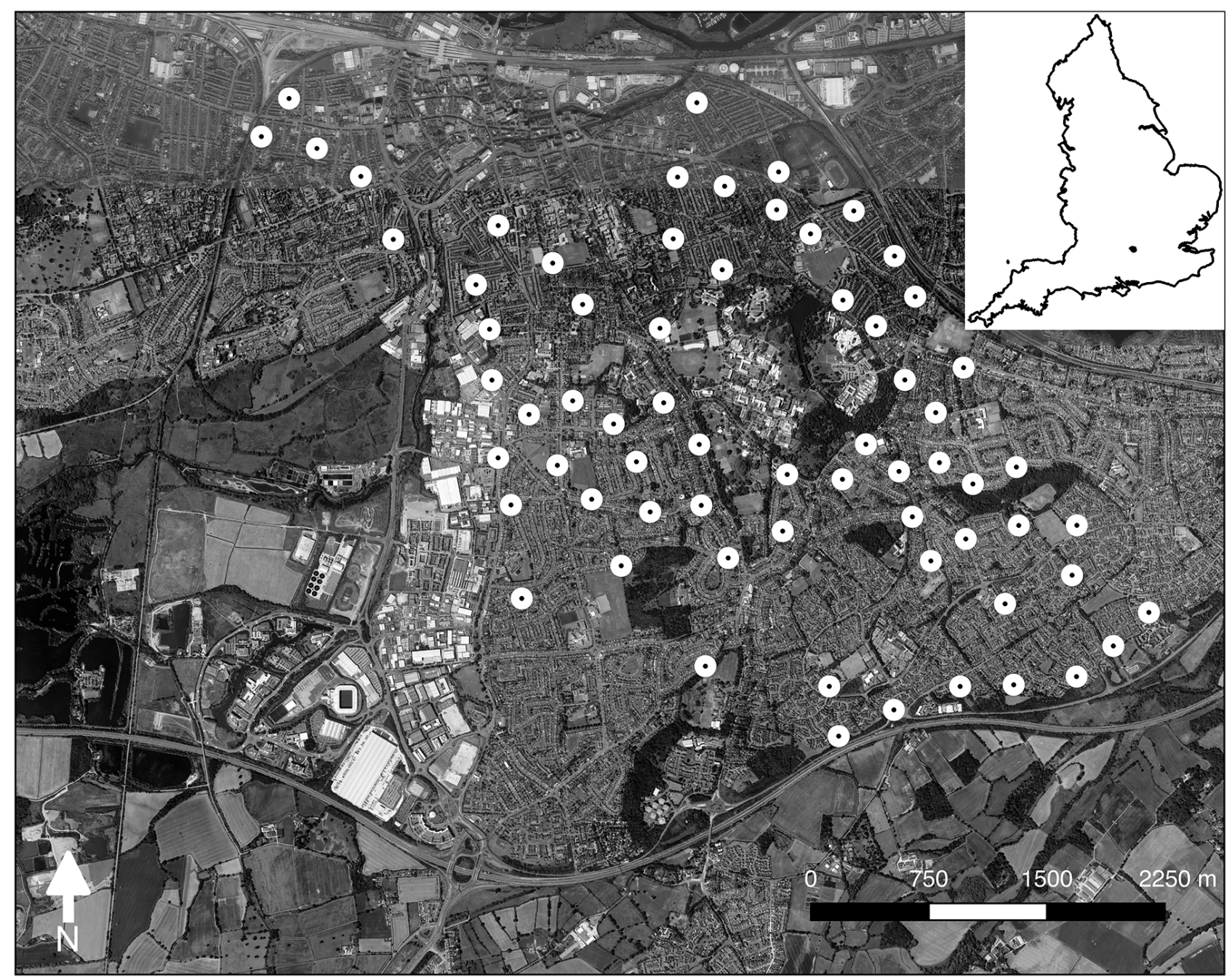

Fig. 1. Location of sampling sites $(n=67)$ in Greater Reading, England. Aerial imagery obtained from the Ordnance Survey Edina MasterMap $^{\circledR}$.

plants, and small trees. Although trees are important host plants for aphids, we limited our sampling to only small individuals that could be fully searched during our experiment for consistency during data collection. All adult ladybirds and aphids were collected by aspiration and placed in Eppendorf tubes filled with $70 \%$ ethanol. Aphid host plants were identified to genus to facilitate aphid identification (Streeter et al., 2016). Aphid abundance was estimated on-site using hand counters. Hoverfly and ladybird larvae were collected with paint brushes and cotton swabs, and kept separately from collected aphids and adult ladybirds in Eppendorf tubes, and stored in $\mathrm{a}-20^{\circ} \mathrm{C}$ freezer.

To determine the diversity of hoverfly adults, standardised point counts, each lasting 5 min and executed by 3 people, were performed in each garden, and individuals were collected for identification with sweep nets (collection of individuals was made outside the standardized point count time). Although not all hoverfly larvae species feed on aphids (only about $40 \%$ of British species are aphid predators, Ball et al., 2013), we decided to consider all hoverfly species (both as larvae and adults) in our survey, and analysed only aphidophagous and all hoverfly species separately in order to have a comprehensive picture of the diversity of this group in this study.

Insect samples were returned to the laboratory for identification to species level for hoverfly and ladybird individuals (keys used: Gilbert, 1986; Majerus \& Kearns, 1989; Rotheray, 1989; Ball et al., 2013), and aphids to morphospecies and species level (keys used: Blackman \& Eastop, 1994, 2008). Aphid identification to species level was not always possible due to the lack of adults in samples.

Aphid host plants were counted and identified to genus or species level. Only host plant species harbouring aphid colonies were counted and considered in each particular garden, therefore if a plant that had aphid colonies in one garden was also present in another garden but with no aphid colonies the abundance of the same plant species was not included as host plant numbers for that particular garden with no aphid colonies. Plant richness was estimated by visually counting plant morphospecies in each garden. Although this method is not adequate for the taxonomic censusing of plants in a particular area, it has shown to be strongly correlated with species richness and to effectively capture variance between study sites with the advantage of reduced sampling effort (Abadie et al., 2008; Schmiedel et al., 2016). Each study site was sampled only once.

\section{Habitat variables}

The proportion of impervious surfaces surrounding each garden was obtained using geographic information system (GIS) procedures, utilising the topography layer from the Ordnance Survey MasterMap ${ }^{\circledR}$, at a scale of 1:1250 m. Using QGIS 2.8.1 (QGIS Development Team, 2015), 100 m radius buffers were delimited from each study site, and a reclassification of vectors was made in order to quantify the proportion of area within those buff- 
ers made of impervious surfaces (e.g., man-made buildings and structures and roads). In addition, the area $\left(\mathrm{m}^{2}\right)$ of each garden, comprised of both the back and front gardens when present, was also obtained.

We initially planned to only select gardens that are not sprayed with insecticide for this study. However, we found that most garden owners who volunteered for this study utilised at least one form of insect control that might influence colonization and survival of aphids and their associated syrphid and coccinellid predators. Therefore, we created a classification of garden disturbance/management to utilise as an explanatory variable in our models. These categorical variables include, (1) no, or very low intervention: no use of insecticides or use of practices deemed unlikely to have a great effect on insect recruitment (e.g. use of slug pellets, weed killers and other forms of insect control such as handpicking, netting); (2) mild, not recent intervention: no use of insecticides this year, but were used in the past two years; (3) high, or recent intervention: recent use of insecticides (partially, or on the majority of plants in the garden).

\section{Analysis}

Statistical analyses were carried out using R 3.1.2 (R Development Core Team, 2014). Aphid species richness (the total number of species found in each study site) was modelled using a generalised linear model (GLM) with a Poisson distribution and a log link function (Zuur et al., 2009), and aphid abundance was modelled using a GLM with negative binomial distribution and a log link function (Crawley, 2007; Zuur et al., 2009) using the MASS package (Ripley, 2015). As explanatory variables, we used the sum of all predator abundances (abundance of ladybirds and aphidophagous hoverflies, larvae and adults), abundance of utilised host plants available in a garden, garden plant richness, garden area, proportion of impervious surfaces within a $100 \mathrm{~m}$ radius buffer, and garden disturbance/management classification (as described above).

Species richness of both hoverflies and ladybirds were not used as response variables in our models due to the lower numbers of species and low levels of variation amongst gardens. To explore which factors determine the abundance of all hoverflies and ladybirds (larvae and adults) in our study sites we performed GLMs, and as these variables were overdispersed, we used a negative binomial distribution and a log link function (Crawley, 2007; Zuur et al., 2009) using the MASS package (Ripley, 2015). As numbers of aphidophagous hoverflies were quite low and none were found in many gardens, we modelled their occurrence (presence or absence) as larvae and adults through a GLM with a binomial distribution and logit link function (Crawley, 2007). As explanatory variables, we used the total abundance of aphids, garden plant richness, garden area, proportion of impervious surfaces, and garden disturbance. In order to deal with extreme values and facilitate model fitting and convergence in all models, the explanatory variables total aphid abundance, garden area and host plant abundance were log-transformed, and predator abundance were square-root transformed. As each study site was sampled only once and the time period of sampling lasted for about a month, to address a possible effect of time on the variation of aphid and predator populations, all models considered sampling date (Julian day) as an explanatory factor.

Model selection was made using Akaike's Information Criteria (AIC), by fitting the full model with the set of all explanatory variables and removing the least significant term at each step, then refitting the model each time until the optimal model (with the lowest AIC) and optimal set of explanatory factors was found (Crawley, 2007; Bolker et al., 2009; Zuur et al., 2009). We checked for collinearity between explanatory variables in our models through variance inflation factors (VIF), which are used as an indicator of multicollinearity in multiple regression, with VIF values higher than 3 indicating that covariation between predictors may impose a problem (Zuur et al., 2007). Our VIF values ranged between 1.03 and 2.40. The response variables and model residuals were checked for spatial autocorrelation through spline correlograms on package ncf (Bjornstad, 2015), in which we did not find any significant spatial structure.

\section{RESULTS}

We observed 45 aphid species (179917 individuals in total), 15 hoverfly species (494 individuals), and 8 ladybird species (173 individuals) (Table 1). About four aphid colonies/species were identified to morphospecies. The ants Myrmica rubra (Linnaeus, 1758) and Lasius niger (Linnaeus, 1758), were found tending aphid colonies on $87 \%$ of the study sites that contained aphid colonies (61 gardens in total had aphid colonies present), M. rubra however, was only seen in four sampling sites. The proportion of habitat elements and their maximum and minimum values are shown in Table 2. a

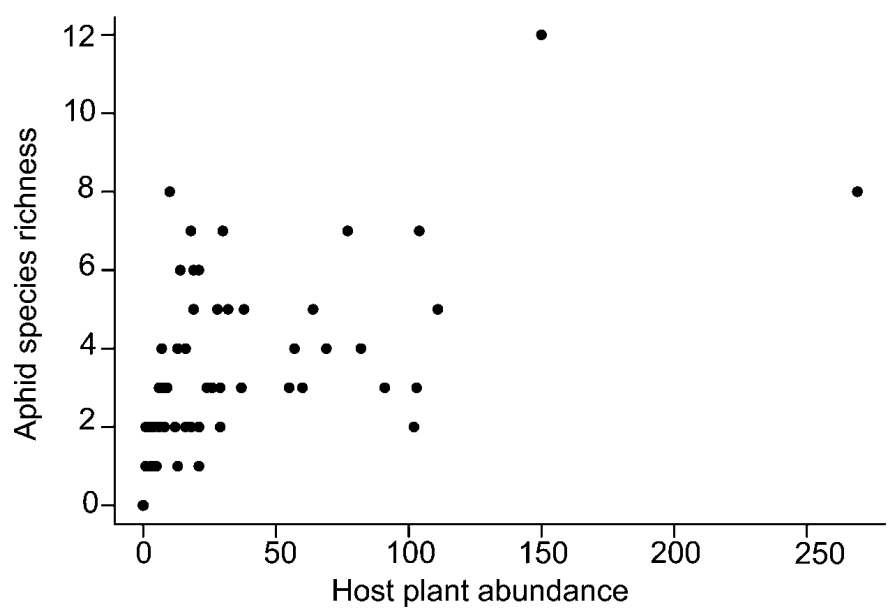

b

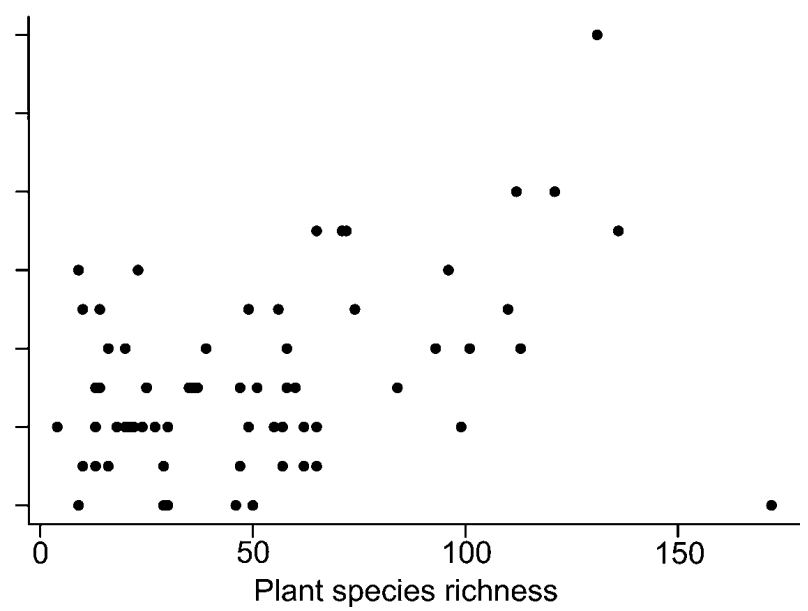

Fig. 2. Aphid species richness compared to (a) host plant abundance and (b) plant species diversity in urban gardens across Reading, UK. 
Table 1. Aphid, ladybird and hoverfly species (adult and larvae) and respective frequency of occurrence in the 67 gardens sampled in this study. $\left(^{*}\right)$ represents non-native status, $(\times)$ denotes non-aphidophagous species $(C$. renipustulatus primarily predates coccids, but has been recorded predating aphids).

\begin{tabular}{lc}
\hline Insecta & Frequency of \\
occurrence $(\%)$
\end{tabular}

\section{Hemiptera \\ Aphididae}

Aphis fabae Scopoli, 1763

Aphis gossypii Glover, 1877

Macrosiphum euphorbiae (Thomas, 1878)

Longicaudus trirhodus (Walker, 1849)

Uroleucon hypochoeridis (Hille Ris Lambers, 1939)

Macrosiphum rosae (Linnaeus, 1758)

Aphis craccivora Koch, 1854

Brachycaudus cardui (Linnaeus, 1758)

Brachycaudus helichrysi Kaltenbach, 1843

Sitobion fragariae (Walker, 1848)

Aphis epilobii Kaltenbach, 1843

Aphis grossulariae Kaltenbach, 1843

Aphis pomi De Geer, 1773

Aphis urticata Gmelin, 1790

Hyperomyzus lactucae (Linnaeus, 1758)

Maculolachnus submacula (Walker, 1848)

Myzus cerasi (Fabricius, 1775)

Anoecia corni (Fabricius, 1775)

Callipterinella tuberculata (von Heyden, 1837)

Aphis brohmeri Börner, 1952

Aphis epilobiaria Theobald, 1927

Aphis frangulae Kaltenbach, 1845

Aphis nasturtii Kaltenbach, 1843

Aphis parietariae Theobald, 1922

Aphis ruborum (Börner, 1932)

Aphis schneideri (Börner, 1940)

Aphis taraxacicola (Börner, 1940)

Aphis verbasci Schrank, 1801

Brachycaudus tragopogonis Kaltenbach, 1843

Chaetosiphon fragaefolii (Cockerell, 1901)

Drepanosiphum platanoidis (Schrank, 1801)

Dysaphis aucupariae (Buckton, 1879)

Macrosiphoniella millefolii (De Geer, 1773)

Macrosiphum funestum Macchiati, 1885

Myzocallis coryli (Goeze, 1778)

Myzus ornatus Laing, 1932

Myzus varians Davidson, 1912

Nasonovia ribisnigri (Mosley, 1841)

Symydobius oblongus (von Heyden, 1837)

Uroleucon picridis (Fabricius, 1775)

Wahlgreniella nervata (Gillette, 1908)

Diptera

Syrphidae

Episyrphus balteatus (De Geer, 1776)

Syritta pipiens (Linnaeus, 1758)

Platycheirus albimanus (Fabricius, 1781)

Melanostoma scalare (Fabricius, 1794)

Melanostoma mellinum (Linnaeus, 1758)

Eupeodes luniger (Meigen, 1822)

Sphaerophoria scripta (Linnaeus, 1758)

Epistrophe eligans (Harris, 1780)

Syrphus ribesii (Linnaeus, 1758)

Platycheirus scutatus (Meigen, 1822)

Baccha elongata (Fabricius, 1794)

Chrysotoxum festivum (Linnaeus, 1758)

Eupeodes corollae (Fabricius, 1794)

Myathropa florea (Linnaeus, 1758)

Eristalis tenax (Linnaeus, 1758)

\section{Coleoptera}

Coccinellidae

Harmonia axyridis (Pallas, 1773)

Propylea quatuordecimpunctata (Linnaeus, 1758)

Coccinella septempunctata (Linnaeus, 1758)

Psyllobora vigintiduopunctata (Linnaeus, 1758)

Halyzia sedecimguttata (Linnaeus, 1758)

Adalia decempunctata (Linnaeus, 1758)

Exochomus quadripustulatus (Linnaeus, 1758)

Chilocorus renipustulatus (Scriba, 1791)
77.61

28.36 *

16.42 *

8.96

8.96

7.46

5.97

5.97

5.97

5.97

4.48

4.48

4.48

4.48

4.48

4.48

4.48

2.99

2.99

1.49

1.49

1.49

1.49

1.49

1.49

1.49

1.49

1.49

1.49

1.49

1.49

1.49

1.49

1.49

1.49

1.49

1.49 *

1.49

1.49

1.49

1.49 *

46.27

$13.43 \times$

10.45

8.96

$4.48 \times$

2.99

2.99

1.49

1.49

1.49

1.49

$1.49 \times$

1.49

$1.49 \times$

$1.49 \times$

32.84 *

20.90

7.46

$2.99 \times$

2.99

1.49

1.49

1.49
Table 2. Mean ( $\pm S E$ ) and range of habitat elements within $30 \mathrm{~m}$ buffers of the study sites.

\begin{tabular}{lcccc}
\hline & $\begin{array}{c}\text { Host plant } \\
\text { abundance }(\mathrm{n})\end{array}$ & $\begin{array}{c}\text { Plant diversity } \\
(\mathrm{n})\end{array}$ & $\begin{array}{c}\text { Garden area } \\
\left(\mathrm{m}^{2}\right)\end{array}$ & $\begin{array}{c}\text { Impervious } \\
\text { surfaces }(\%)\end{array}$ \\
\hline $\begin{array}{l}\text { Mean } \\
( \pm \mathrm{SE})\end{array}$ & $30.33 \pm 5.44$ & $49.75 \pm 4.84$ & $340.96 \pm 37.21$ & $39 \pm 1$ \\
Range & $0-269$ & $4-172$ & $28.91-1653.56$ & $17-71$ \\
\hline
\end{tabular}

\section{Direct and indirect environmental factors determining aphid, ladybird and hoverfly numbers in urban gardens}

Aphid species richness: this variable was best explained by the abundance of utilised host plants and plant species richness within each garden (Table 3, model 1, Fig. 2). Garden disturbance/management, proportion of impervious surfaces, Julian day, garden area and predator abundance were removed due to non-significance and low explanatory power during the model selection process in that respective order.

Aphid abundance: the most parsimonious model explaining aphid numbers had only one variable, which was the abundance of host plants (Table 3, model 2, Fig. 3).

Total abundance of hoverflies: the best model for explaining the total abundance of hoverflies had only one explanatory variable, which was garden plant richness (positively correlated, Table 3, model 3, Fig. 4). Other explanatory variables (garden area, Julian day, aphid abundances, and garden disturbance/management) were removed during the model selection process when related to this variable.

Occurrence of aphidophagous hoverflies: the final model that explains occurrence of aphidophagous hoverflies (presence or absence) was best explained by two explanatory variables (a) garden plant richness, which was positively and significantly related to aphidophagous hoverfly presence and (b) garden disturbance/management, with low levels of garden management positively related to the presence of aphidophagous hoverflies, however this factor was not statistically significant (Table 3, model 4, Fig. 5).

Ladybird abundance: the best model describing variance in ladybird abundance had three variables: aphid abundance and plant species diversity, which were positively and significantly correlated with ladybird abundance, and

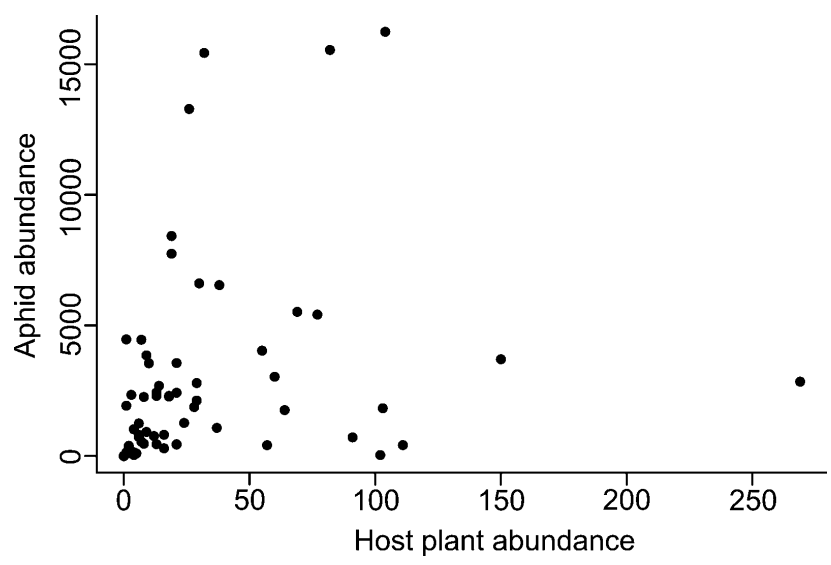

Fig. 3. Aphid abundance compared to host plant abundance in urban gardens across Reading, UK. 


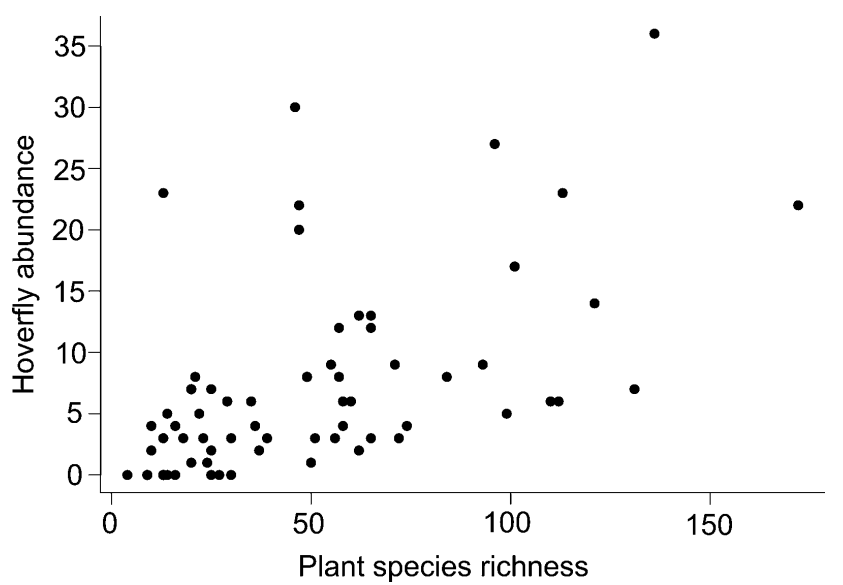

Fig. 4. Hoverfly abundance in relation to plant species diversity in urban gardens across Reading, UK.

the proportion of impervious surfaces in a $100 \mathrm{~m}$ radius buffer, which was negatively correlated with the abundance of ladybirds (Table 3, model 5, Fig. 6). Garden area, Julian day and garden management levels were removed during the model simplification process due to low explanatory power when predicting this variable.

\section{DISCUSSION}

In this study, we found that aphid species richness and abundance were positively associated with utilised host plant abundance and garden plant species diversity, both traits of gardens largely determined by the homeowner. In particular, garden plant diversity was the main determinant of all groups investigated. Hoverfly numbers (including all specimens and aphidophagous species alone) increased with garden plant diversity, and for aphidophagous hoverflies increased abundance was associated with low insecticide use and low garden disturbance (albeit not statistically significant; Table 3, model 4). Ladybird abundance was positively correlated with aphid abundance and garden plant species diversity, and negatively associated with the proportion of impervious surfaces. The difference in responses between the two major taxa of aphid predators may reflect differences in behaviour and natural his-

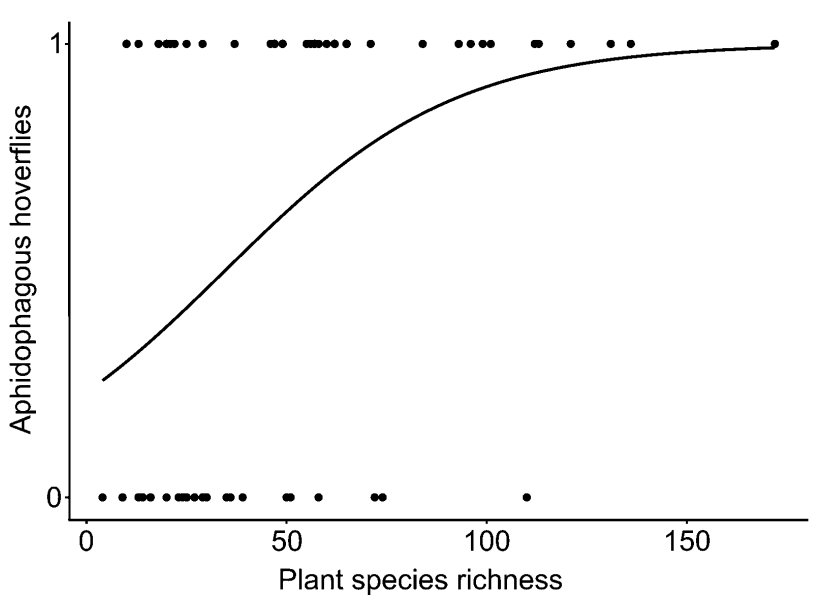

Fig. 5. Representation of logistic regression model of plant species diversity present in urban gardens determining the presence (1) or absence (0) of aphidophagous hoverflies.

tory. While the larvae of both groups are aphidophagous, as are adult ladybirds, adult hoverflies feed upon pollen and nectar, and therefore do not depend on aphid numbers as ladybirds do.

As sessile and specialised phytophagous groups, aphids are undoubtedly intrinsically linked to plant diversity and structure, and are known to be affected by plant diversity manipulation in grasslands (Koricheva et al., 2000). Many species of aphids exhibit host alternation, where different generations live on two taxonomically unrelated host plants (Rotheray, 1989). Aphids can therefore be considered "sequential polyphages" (Andow, 1991) and may reach higher densities on areas that contain several plant functional groups because such places are more likely to contain both the primary and the secondary host plants (Koricheva et al., 2000). Therefore, the positive association of aphid species richness and abundance with garden plant diversity and utilised host plant numbers found in our study was not surprising. Urban gardens are areas of exceptionally high levels of plant diversity. In comparison to other habitats (e.g. car parks, churchyards), residential gardens present higher plant species richness (1056 species in 267 gardens of five UK cities; Gaston et al., 2007; Goddard

Table 3. Summary of best models predicting aphid species richness and abundance (models 1 and 2 ), and abundance and occurrence of hoverflies (models 3 and 4 ) and ladybirds (model 5) in urban gardens across Reading, UK. AIC values for each model are given, and significant explanatory factors are shown in bold.

\begin{tabular}{|c|c|c|c|c|c|}
\hline Model ID & $\mathrm{AIC}$ & Response variable & Explanatory variable & Coefficient value \pm SE & $P$ \\
\hline \multirow[t]{3}{*}{1} & 241.76 & Aphid richness & Intercept & $-0.084 \pm 0.192$ & 0.662 \\
\hline & & & Host plant abundance & $0.772 \pm 0.125$ & 7.13E-10 \\
\hline & & & Plant diversity & $0.005 \pm 0.002$ & 0.01 \\
\hline \multirow[t]{2}{*}{2} & 1137.2 & Aphid abundance & Intercept & $5.917 \pm 0.364$ & $2.00 \mathrm{E}-16$ \\
\hline & & & Host plant abundance & $1.504 \pm 0.284$ & 1.16E-07 \\
\hline \multirow[t]{2}{*}{3} & 397.46 & Hoverfly general & Intercept & $1.156 \pm 0.195$ & $3.24 \mathrm{E}-09$ \\
\hline & & & Plant diversity & $0.014 \pm 0.003$ & 2.76E-06 \\
\hline \multirow[t]{3}{*}{4} & 78.193 & Hoverfly aphidophagous & Intercept & $-3.915 \pm 1.578$ & 1.30E-02 \\
\hline & & & Plant diversity & $0.049 \pm 0.014$ & $7.88 \mathrm{E}-04$ \\
\hline & & & Low intervention & $2.334 \pm 1.244$ & 0.061 \\
\hline \multirow[t]{4}{*}{5} & 237.26 & Ladybird & Intercept & $-2.017 \pm 0.952$ & 0.034 \\
\hline & & & Aphid abundance & $0.873 \pm 0.222$ & 8.36E-05 \\
\hline & & & Plant diversity & $0.018 \pm 0.005$ & $6.72 \mathrm{E}-05$ \\
\hline & & & Impervious surfaces & $-3.016 \pm 1.530$ & 0.049 \\
\hline
\end{tabular}


a

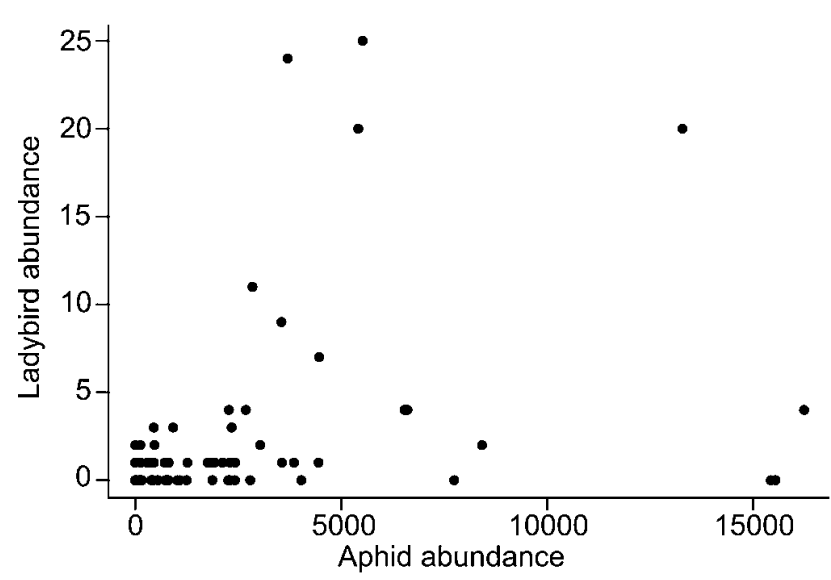

b

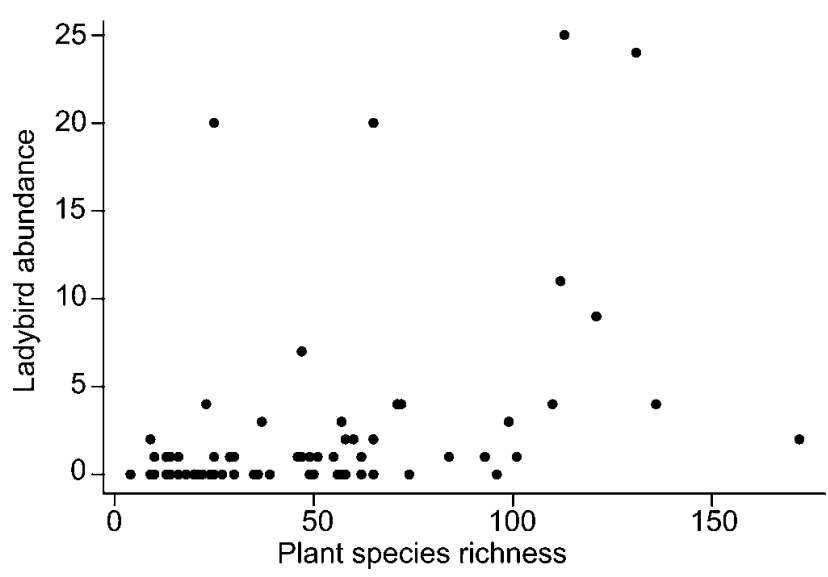

c

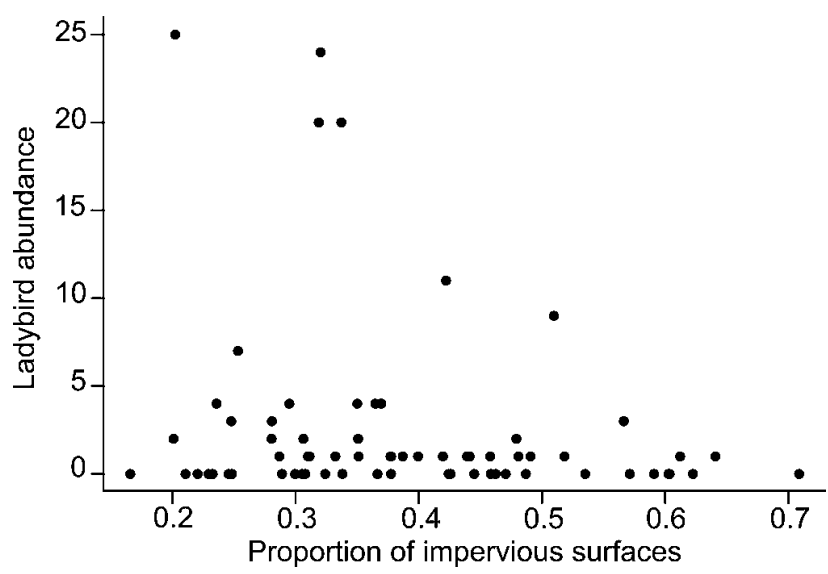

Fig. 6. Ladybird abundance in relation to (a) aphid abundance, (b) plant species diversity and (c) proportion of impervious surfaces in urban gardens across Reading, UK.

et al., 2010) and may also receive higher inputs of fertiliser affecting plant quality, which could affect aphid numbers (Müller et al., 2005). In our samples, we found four nonnative species of aphid (Macrosiphum euphorbiae, Aphis gossypii, Myzus varians and Wahlgreniella nervata). How the presence of non-native aphid species may be a consequence of gardening practices is not known. We found no evidence of an association between increased urbanisation (e.g. increased impervious surfaces) and aphid diversity. It is worth noting that parasitoid wasps are important and at times abundant natural enemies of aphids in surrounding farmland (Hazell \& Fellowes, 2009), and appear to be less frequent in local urban areas (Rocha \& Fellowes, 2018), but these were not considered in this study. Parasitoids may provide a part explanation for some of the unexplained variation in aphid abundance, but future investigations of this group in domestic gardens is needed, particularly from the perspective of the ecosystem services they provide.

Hoverfly abundance was positively associated with increased garden plant diversity, which was not surprising given that adults feed on the pollen and nectar of flowering plants (Haenke et al., 2009; Moquet et al., 2018). Consequently, it is expected that hoverfly abundance and diversity will be greater in plant diverse habitats, such as gardens and flower-rich field margins (Cowgill et al., 1993; Hickman \& Wratten, 1996; Haenke et al., 2009). Hoverflies were not affected by our measure of urbanisation, which was the amount of impervious surfaces within 100 $\mathrm{m}$ radius buffers. Given that hoverflies are highly mobile, it appears that in our study area, urbanisation presented few barriers to dispersal (Bernard \& Stavenga, 1979; Lunau \& Wacht, 1994; Haenke et al., 2009). Although similar studies have reported that the abundance of hoverflies may be correlated with local and fine-scale environmental variables (Smith et al., 2006), we did not find evidence of this in our study system.

A characteristic typical of many predatory ladybirds is the aggregation of individuals on plants that contain abundant prey. Consequently, the composition of these communities is determined by prey identity, their numbers, microclimate and plant composition (Ferrer et al., 2016; Honek et al., 2017). Our results corroborate these characteristics, since ladybird numbers increased with total numbers of aphids and plant diversity in gardens. Ladybird abundance declined as the proportion of impervious surfaces surrounding each garden increased. Urban land cover can increase the likelihood of local extinction and reduce the likelihood of colonisation for ladybird beetles in the UK (Comont et al., 2014). Therefore, while gardens and parks in urban areas often seem to be favourable for some species of ladybird, our results indicate that overall increases in urban land cover are not favourable for ladybirds as a group, a conclusion also drawn by Comont et al. (2014), who suggest that urban areas are probably beneficial for a small subset of habitat generalist species but poor for more specialist species.

Natural enemies are vital for the management and function of green spaces, since they are crucial agents of biological control of damaging pests (Burkman \& Gardiner, 2014). Our results suggest fragmentation and reductions in urban green space may represent threats to biodiversity and consequently the ecosystem services they provide. Urban green spaces can help reduce effects of urbanisation by providing suitable resources and habitat among the urban matrix (Smith et al., 2006). Urban gardens associated with residential areas are an important component of 
urban green spaces, often providing valuable conservation services and harbouring a great parcel of the biodiversity present in a region (Owen, 1991; Gaston et al., 2005; Loram et al., 2007). An often unrecognized aspect of urban gardens is that they enable people to perceive and appreciate nature, which directly benefits human mental health (Cannon, 1999; Smith et al., 2006). Our current understanding of how species respond to urbanisation is limited to a relatively small number of well-studied taxa. We show that for our study system, the planting decisions made by garden owners can have a significant effect on the diversity and abundance of aphids and their natural enemies. We focused on patterns of diversity of important groups of invertebrates found in urban gardens, however there is still much to be learned about the factors determining the diversity of many other taxa, as well as the most appropriate garden management actions that will benefit biodiversity in such habitats.

ACKNOWLEDGEMENTS. We would like to thank all garden owners for participating on this study. CAPES foundation (Brazil) provided funding for this work and scholarship for the first author, BEX: 13531-13-1. Data are available on request from MDEF. We are also thankful to J. Hawkins for help with host plant identification. We are grateful to two anonymous referees for their efforts in helping greatly improve our manuscript.

\section{REFERENCES}

Abadie J.C., Andrade C., Machon N. \& Porcher E. 2008: On the use of parataxonomy in biodiversity monitoring: a case study on wild flora. - Biodiv. Conserv. 17: 3485-3500.

Andow D.A. 1991: Vegetational diversity and arthropod population response. - Annu. Rev. Entomol. 36: 561-586.

Andrade R., Bateman H.L. \& Kang Y. 2017: Seasonality and land cover characteristics drive aphid dynamics in an arid city. - J. Arid Environ. 144: 12-20.

Aronson M.F., Nilon C.H., Lepczyk C.A., Parker T.S., Warren P.S., Cilliers S.S., Goddard M.A., Hahs A.K., Herzog C. \& KаттI M. 2016: Hierarchical filters determine community assembly of urban species pools. - Ecology 97: 2952-2963.

Baldock K.C., Goddard M.A., Hicks D.M., Kunin W.E., MitsChunas N., Osgathorpe L.M., Potts S.G., Robertson K.M., Scott A.V. \& Stone G.N. 2015: Where is the UK's pollinator biodiversity? The importance of urban areas for flower-visiting insects. - Proc. R. Soc. Lond. (B) 282: 10 pp.

Ball S., Ball S. \& Morris R. 2013: Britain's Hoverflies: An Introduction to the Hoverflies of Britain. Princeton University Press, New Jersey, 312 pp.

Barratt B.I., Dickinson K.J., Freeman C., Porter S., Johnstone P.D., Wing J. \& HeEzIK Y. 2015: Biodiversity of Coleoptera and other invertebrates in urban gardens: a case study in a New Zealand city. - Insect Conserv. Div. 8: 428-437.

Bates A.J., Sadler J.P., Fairbrass A.J., Falk S.J., Hale J.D. \& Matthews T.J. 2011: Changing bee and hoverfly pollinator assemblages along an urban-rural gradient. — PLOS ONE 6(8): e23459, $11 \mathrm{pp}$.

Bernard G.D. \& Stavenga D.G. 1979: Spectral sensitivities of retinular cells measured in intact, living flies by an optical method. - J. Compar. Physiol. (A) 134: 95-107.

BJoRnSTAD O.N. 2015: Package 'ncf': Spatial nonparametric covariance functions. Ver. 1.1-6. URL: https://cran.r-project.org/ web/packages/ncf/index.html (last accessed 4 Jan. 2015).
BLACKMAN R.L. \& EASTOP V.F. 1994: Aphids on the World's Trees: An Identification and Information Guide. CAB International, Michigan, $987 \mathrm{pp}$.

Blackman R.L. \& EAstop V.F. 2008: Aphids on the World's Herbaceous Plants and Shrubs. John Wiley \& Sons, London, 1460 pp.

Bolker B.M., Brooks M.E., Clark C.J., Geange S.W., Poulsen J.R., Stevens M.H.H. \& White J.-S.S. 2009: Generalized linear mixed models: a practical guide for ecology and evolution. Trends Ecol. Evol. 24: 127-135.

Brisson J.A. \& STERn D.L. 2006: The pea aphid, Acyrthosiphon pisum: an emerging genomic model system for ecological, developmental and evolutionary studies. - Bioessays 28: 747755.

BuRKMAN C.E. \& GARDINER M.M. 2014: Urban greenspace composition and landscape context influence natural enemy community composition and function. - Biol. Contr. 75: 58-67.

CANNON A. 1999: The significance of private gardens for bird conservation. - Bird Conserv. Int. 9: 287-297.

Comont R.F., Roy H.E., Harrington R., Shortall C.R. \& Purse B.V. 2014: Ecological correlates of local extinction and colonisation in the British ladybird beetles (Coleoptera: Coccinellidae). - Biol. Invas. 16: 1805-1817.

Cowgill S., Sotherton N. \& Wratten S. 1993: The selective use of floral resources by the hoverfly Episyrphus balteatus (Diptera: Syrphidae) on farmland. - Ann. Appl. Biol. 122: 223-231.

Crawley M.J. 2007: The R Book. John Wiley \& Sons, Chichester, UK, $1080 \mathrm{pp}$.

Dale A.G. \& Frank S.D. 2014: Urban warming trumps natural enemy regulation of herbivorous pests. - Ecol. Appl. 24: $1596-1607$.

Faeth S.H., Warren P.S., Shochat E. \& Marussich W.A. 2005: Trophic dynamics in urban communities. - Bioscience 55: 399-407.

FATTORINI S. 2011: Insect extinction by urbanization: a long term study in Rome. - Biol. Conserv. 144: 370-375.

Ferrer A., Dixon A.F.G. \& Hemptinne J.L. 2016: Habitat or prey specialization in predatory ladybird beetles: a case study of two closely related species. - J. Appl. Entomol. 140: 199-208.

FranKiE G.W. \& EhLER L. 1978: Ecology of insects in urban environments. - Annu. Rev. Entomol. 23: 367-387.

Gardiner M.M., Prajzner S.P., Burkman C.E., Albro S. \& GreWAL P.S. 2014: Vacant land conversion to community gardens: influences on generalist arthropod predators and biocontrol services in urban greenspaces. - Urban Ecosyst. 17: 101-122.

Gaston K.J., Warren P.H., Thompson K. \& Smith R.M. 2005: Urban domestic gardens (IV): The extent of the resource and its associated features. - Biodiv. Conserv. 14: 3327-3349.

Gaston K.J., Fuller R.A., Loram A., MacDonald C., Power S. \& DempSEY N. 2007: Urban domestic gardens (XI): variation in urban wildlife gardening in the United Kingdom. - Biodiv. Conserv. 16: 3227-3238.

Gilbert F. 1986: Hoverflies. Naturalists' Handbook 5. Pelagic Publishing, Cambridge, 96 pp.

Giorgi J.A., Vandenberg N.J., McHugh J.V., Forrester J.A., ŚlipińSKi S.A., Miller K.B., Shapiro L.R. \& Whiting M.F. 2009: The evolution of food preferences in Coccinellidae. Biol. Contr. 51: 215-231.

Goddard M.A., Dougill A.J. \& Benton T.G. 2010: Scaling up from gardens: biodiversity conservation in urban environments. - Trends Ecol. Evol. 25: 90-98.

Haenke S., Scheid B., Schaefer M., Tscharntke T. \& Thies C. 2009: Increasing syrphid fly diversity and density in sown 
flower strips within simple vs. complex landscapes. - J. Appl. Ecol. 46: 1106-1114.

Hazell S.P. \& Fellowes M.D.E. 2009: Clonal variation affects the structure of the natural enemy assemblage attacking an insect herbivore. - Ecol. Entomol. 34: 34-42.

Hennig E.I. \& Ghazoul J. 2012: Pollinating animals in the urban environment. - Urban Ecosyst. 15: 149-166.

Hickman J.M. \& Wratten S.D. 1996: Use of Phelia tanacetifolia strips to enhance biological control of aphids by hoverfly larvae in cereal fields. - J. Econ. Entomol. 89: 832-840.

HironaKa Y. \& KoIKe F. 2013: Guild structure in the food web of grassland arthropod communities along an urban-rural landscape gradient. - Ecoscience 20: 148-160.

Honek A., Dixon A.F., Soares A.O., Skuhrovec J. \& Martinkova Z. 2017: Spatial and temporal changes in the abundance and compostion of ladybird (Coleoptera: Coccinellidae) communities. - Curr. Opin. Insect Sci. 20: 61-67.

Jauker F., Bondarenko B., Becker H.C. \& Steffan-Dewenter I. 2012: Pollination efficiency of wild bees and hoverflies provided to oilseed rape. - Agr. For. Entomol. 14: 81-87.

JONES E.L. \& LEATHER S.R. 2012: Invertebrates in urban areas: a review. — Eur. J. Entomol. 109: 463-478.

Kaye J.P., Groffman P.M., Grimm N.B., BaKer L.A. \& Pouyat R.V. 2006: A distinct urban biogeochemistry? - Trends Ecol. Evol. 21: 192-199.

KIм H.H. 1992: Urban heat island. - Int. J. Remote Sensing 13 2319-2336.

Koricheva J., Mulder C.P., Schmid B., Joshi J. \& Huss-Danell K. 2000: Numerical responses of different trophic groups of invertebrates to manipulations of plant diversity in grasslands. -Oecologia 125: 271-282.

Loram A., Tratalos J., Warren P.H. \& Gaston K.J. 2007: Urban domestic gardens $(\mathrm{X})$ : The extent \& structure of the resource in five major cities. - Landsc. Ecol. 22: 601-615.

LUNAU K. \& WACHT S. 1994: Optical releasers of the innate proboscis extension in the hoverfly Eristalis tenax 1. (Syrphidae, Diptera). - J. Compar. Physiol. (A) 174: 575-579.

Majerus M. \& Kearns P. 1989: Ladybirds. Naturalists' Handbook 10. Richmond Publishing, Slough, 142 pp.

Marzluff J.M. \& Ewing K. 2001: Restoration of fragmented landscapes for the conservation of birds: a general framework and specific recommendations for urbanizing landscapes. Restor. Ecol. 9: 280-292.

McDonald R.I., Kareiva P. \& Forman R.T. 2008: The implications of current and future urbanization for global protected areas and biodiversity conservation. - Biol. Conserv. 141: 1695-1703.

McKinNey M.L. 2008: Effects of urbanization on species richness: a review of plants and animals. - Urban Ecosyst. 11: 161-176.

Meineke E.K., Dunn R.R. \& FranK S.D. 2014: Early pest development and loss of biological control are associated with urban warming. — Biol. Lett. 10: 20140586, 4 pp.

Meyer B., Jauker F. \& Steffan-Dewenter I. 2009: Contrasting resource-dependent responses of hoverfly richness and density to landscape structure. - Basic Appl. Ecol. 10: 178-186.

Moquet L., Laurent E., Bacchetta R. \& Jacquemart A.L. 2018: Conservation of hoverflies (Diptera, Syrphidae) requires complementary resources at the landscape and local scales. - Insect Conserv. Div. 11: 72-87.

Müller C.B., Fellowes M.D.E. \& Godfray H.C.J. 2005: Relative importance of fertilizer addition and exclusion of predators for aphid growth in the field. - Oecologia 139: 419-427.
Obrycki J.J., Harwood J.D., Kring T.J. \& O’Neil R.J. 2009: Aphidophagy by Coccinellidae: application of biological control in agroecosystems. - Biol. Contr. 51: 244-254.

Oerke E.C., Dehne H.-W., Schönbeck F. \& Weber A. 2012: Crop Production and Crop Protection: Estimated Losses in Major Food and Cash Crops. Elsevier, Amsterdam, 829 pp.

Office for National Statistics 2013: Neighbourhood Statistics. 2011 Census Data, Vol. 2013. HM Government. URL: www. neighbourhood.statistics.gov.uk.

OwEN J. 1981: Trophic variety and abundance of hoverflies (Diptera, Syrphidae) in an English suburban garden. - Holarct. Ecol. 4: 221-228.

Owen J. 1991: The Ecology of a Garden: The First Fifteen Years. Cambridge University Press, Cambridge, 403 pp.

Philpott S.M., Cotton J., Bichier P., Friedrich R.L., Moorhead L.C., UNo S. \& VALDEZ M. 2014: Local and landscape drivers of arthropod abundance, richness, and trophic composition in urban habitats. - Urban Ecosyst. 17: 513-532.

QGIS Development Team 2015: Qgis Geographic Information System. Open Source Geospatial Foundation Project. URL: http://qgis.osgeo.org.

R Development Core Team 2014: $R$ : A Language and Environment for Statistical Computing. R Foundation for Statistical Computing. URL: http://www.R-project.org.

Raupp M.J., Shrewsbury P.M. \& Herms D.A. 2010: Ecology of herbivorous arthropods in urban landscapes. - Annu. Rev. Entomol. 55: 19-38.

Ripley B., Venables B., Bates D.B., Hornik K., Gebhardt A. \& FIRTH D. 2015: Package Mass: Support Functions and Datasets for Venables and Ripley's Mass. URL: https://cran.r-project.org/web/packages/MASS/index.html

RochA E.A. \& FelLowes M.D.E. 2018: Does urbanization explain differences in interactions between an insect herbivore and its natural enemies and mutualists? - Urban Ecosyst. 21: online early. DOI: 10.1007/s11252-017-0727-5

Rotheray G.E. 1989: Aphid Predators. Richmond Publishing, Kingston upon Thames, $77 \mathrm{pp}$.

Schmiedel U., Araya Y., Bortolotto M.I., Boeckenhoff L., Hallwachs W., Janzen D., Kolipaka S.S., Novotny V., Palm M., PARFONDRY M. ET AL. 2016: Contributions of paraecologists and parataxonomists to research, conservation, and social development. - Conserv. Biol. 30: 506-519.

Shochat E., Warren P.S., Faeth S.H., McIntyre N.E. \& Hope D. 2006: From patterns to emerging processes in mechanistic urban ecology. — Trends Ecol. Evol. 21: 186-191.

Shrewsbury P.M. \& RaupP M.J. 2006: Do top-down or bottomup forces determine Stephanitis pyrioides abundance in urban landscapes? - Ecol. Appl. 16: 262-272.

Smith L.S. \& FelLowes M.D.E. 2014: The grass-free lawn: management and species choice for optimum ground cover and plant diversity. - Urban For. Urban Green. 13: 433-442.

Smith R.M., Gaston K.J., Warren P.H. \& Thompson K. 2006: Urban domestic gardens (VII): environmental correlates of invertebrate abundance. - Biodiv. Conserv. 15: 2515-2545.

Smith L.S., Broyles M.E.J., Larzleer H.K. \& Fellowes M.D.E. 2015: Adding ecological value to the urban lawnscape: insect abundance and diversity in grass-free lawns. - Biodiv. Conserv. 24: 47-62.

Streeter D., Hart-Davies C., Hardcastle A., Cole F. \& Harper L. 2016: Collins Wild Flower Guide. Harper Collins, London, $704 \mathrm{pp}$.

Weber D.C. \& Lundgren J.G. 2009: Assessing the trophic ecology of the Coccinellidae: their roles as predators and as prey. - Biol. Contr. 51: 199-214. 
Zuur A., Ieno E.N. \& Smith G.M. 2007: Analysing Ecological Data. Springer, New York, 672 pp.
ZuUr A.F., Ieno E.N., Walker N.J., SAveliev A.A. \& Smith G.M. 2009: Mixed Effects Models and Extensions in Ecology with R. Springer, Berlin, Heidelberg, 574 pp.

Received November 9, 2017; revised and accepted April 4, 2018 Published online April 9, 2018 